GEOFIZIKA VOL. $38 \quad 2021$

DOI: https://doi.org /10.15233/gfz.2021.38.8

Preliminary communication

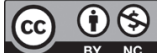

\title{
Calibration of shaking intensity models of the "Extremum" system to simulate loss due to the 2020 Croatia earthquakes
}

\author{
Snježana Markušićc ${ }^{1,}$ Nina Frolova ${ }^{2}$, Irina Gabsatarova ${ }^{3}$, Sergej Suchshev ${ }^{4}$ \\ and Nataliya Malaeva ${ }^{2}$ \\ ${ }^{1}$ Department of Geophysics, Faculty of Science, University of Zagreb, Zagreb, Croatia \\ ${ }^{2}$ Sergeev Institute of Environmental Geoscience, Russian Academy of Sciences, Moscow, Russia \\ ${ }^{3}$ Geophysical Survey, Russian Academy of Sciences, Obninsk, Kaluga Region, Russia \\ ${ }^{4}$ Moscow State Technical University named after Bauman, Moscow, Russia
}

Received 29 June 2021, in final form 3 December 2021

\begin{abstract}
This paper is devoted to applications of the "Extremum" loss simulation system to two damaging earthquakes which occurred in Croatia in 2020 . We provide a calibration procedure of mathematical models used for shaking intensity simulation. The regional macroseismic field parameters, such as the coefficients in the macroseismic field equation; the ratio between the longer $(b)$ and the shorter (a) axes of the higher elliptical isoseismals (the flattening ratio $k$ ); the angle that specifies the orientation of the macroseismic field, in particular, the azimuth of the longer axis in the isoseismal ellipse, were all based on extensive macroseismic data acquired for the Balkan region and on the data for an analogous area with similar seismotectonic parameters in the Caucasus. We obtained a fairly good consistency between the results of simulation applied to the impact of the 2020 Croatia earthquakes and observations, confirming that the calibration of the macroseismic model by the Extremum system was both reasonable and effective for enhancing reliability for real time loss estimation.
\end{abstract}

Keywords: macroseismic field modelling, earthquake loss, near real time estimates, earthquakes, Croatia, "Extremum" loss simulation system

\section{Introduction}

The "Extremum" system is one of the three systems available for near real time loss assessment in application to any area worldwide in order to make adequate decisions on rescue and relief. 
The information about the possible impact of a damaging earthquake that has just occurred is extremely important for decisions on search and rescue operations in order to save lives and property. The reliability of simulated impact which can be provided by global near real time systems in the emergency mode strongly depends on many factors. First of all, it is influenced by the uncertainties in the determination of the earthquake parameters (epicentral coordinates, magnitude, hypocentral depth), as well as the chosen simulation models for shaking intensity distribution and vulnerability functions of elements at risk. At present, the influence of these factors could be minimized by attempting to reduce uncertainties in the determination of earthquake parameters used as input in the emergency mode and by calibrating the global near real time systems based on knowledge of the impact of past events.

This paper is devoted to the "Extremum" system as used for loss simulation due to the 2020 earthquakes in Croatia. Croatia and the Balkan region are characterized by high levels of seismicity, and there are extensive macroseismic data available (Markušić et al., 1996, 1999, 2020, 2021).

We describe a calibration procedure for shaking intensity simulation by the "Extremum" system for the two damaging earthquakes that occurred in Croatia in 2020 (the Zagreb M5.5 earthquake in March and the Petrinja M6.2 earthquake in December). The "Extremum" system allows the user to choose suitable regional characteristics of shaking intensity (by calibration): the Shebalin equation and its regional coefficients, the orientation and the ratio $k$ between the major and minor semi-axes in the ellipse that describes the simulated macroseismic field, which are essential data for reliable loss computations. Similar studies have been previously carried out for the Russian Federation and adjacent territories, as well as for other earthquake prone countries (Frolova et. al., 2018, 2019).

\section{The method and input data}

The "Extremum" system began to be developed in the 1990s by joint efforts of the Extreme Situations Research Center (ESRC) Ltd., the Seismological Center, Institute of Environmental Geosciences, Russian Academy of Sciences, and the Civil Defense and Disaster Management Research Institute, Emercom of Russia, within the framework of the Russian Federal Programs "Safety of Population, Buildings and Structures against Natural and Technological Hazards" and "Federal System of Seismological Observations and Earthquake Prediction" (Methods for forecasting the impact of earthquakes, 2000; Larionov and Frolova, 2003; Larionov et al., 2003). In 1999-2001, the system was further improved within the framework of EDRIM ("Electronic Discussions for Risk Managements"), a program under the umbrella of the EUR-OPA Major Hazards Agreement ("Open Partial Agreement on the Prevention of, Protection Against and 
Organisation of Relief in Major Natural and Technological Disasters") of the Council of Europe.

The "Extremum" system in the Russian Federation was first implemented in 1995 for damage and loss assessment after the 28 May 1995 Neftegorsk M7.6 earthquake. The first implementation at a "global level" followed the recommendations of the Moscow Seminar on "Contribution to the Decision-Making Process in Seismic Risk Management: Models for Earthquake Damage Assessment” held 29 June - 1 July, 2000, within the framework of the EUR-OPA Major Hazards Agreement. Starting 1 August 2000, a version was run on an operational basis to provide quick information on damage and casualties assessment of any earthquake (with magnitudes higher than or equal to 5.5 for the Euro-Mediterranean Region, and magnitudes higher than or equal to 6.5 world-wide) to be transmitted to the network of the Euro-Mediterranean Centres of the Agreement and to specific national institutions appointed by national authorities and to the Executive Secretariat of the Agreement.

The "Extremum" system databases and mathematical models used for simulation of shaking intensity, damage to buildings and structures, number of fatalities and injuries, are regularly updated. The simulation models and databases, as well as reliability issues, are discussed in Frolova et al. (2011, 2017). The results of computations are usually presented as maps and tables, where estimates of expected fatalities, injuries and homeless are reported for the whole stricken area and/or for each city, town, village. The main indicators and risk measures in the "Extremum" system are: the distribution of damage states for buildings of different types classified according to the MMSK-86 scale (Shebalin et al., 1986) for the whole affected area and for each population center; the expected numbers of fatalities and injured (at different rates or levels) for the whole stricken area and for each population center; characteristics of highway blockage and total length of blocked roads; the expected number of trigged ("secondary") technological accidents in the stricken area. These have a direct bearing on the resources and forces which should be involved in search and rescue operations, as well as for identifying the needed humanitarian assistance.

In recent years much effort has been invested, in collaboration with the Geophysical Survey of the Russian Academy of Sciences, to identify specific features in shaking intensity attenuation and its effects on near real time earthquake loss simulation in the emergency mode (Frolova et al., 2019, 2020). The test sites were Russia, CIS (Commonwealth of Independent States, which is the abbreviation of the former USSR countries after the disintegration of the Soviet Union) countries and other, including Albania.

Table 1 lists input data (different scenarios) for computation using the "Extremum" system as applied to the 2020 Zagreb earthquake. Different values of 
Table 1. Input data for simulation of the possible impact due to the 22 March 2020 Zagreb earthquake using the "Extremum" system.

No. Event parameters and source Coefficients of macroseismic field equation (1) (Shebalin, 1968)

Field orientation and ratio coefficient $k$

$45,98^{\circ} \mathrm{N} ; 15,99^{\circ} \mathrm{E} ; m b=5.5 ; h=10 \mathrm{~km} ; b=1.5 ; v=4 ; c=3.8$; Central and

1 (http://mseism.gsras.ru) South-East Europe (Shebalin et al., 1998)

$263^{\circ} ; k=1.5$

2 $45,87^{\circ} \mathrm{N} ; 16,02^{\circ} \mathrm{E} ; M_{w}=5.4 ; h=10 \mathrm{~km} ; b=1.5 ; v=4 ; c=3.8$; Central and

2 (https://www.emsc-csem.org)

South-East Europe (Shebalin et al., 1998)

$345,9^{\circ} \mathrm{N} ; 15,97^{\circ} \mathrm{E} ; M_{w}=5.4 ; h=10 \mathrm{~km} ; \quad b=1.5 ; v=4 ; c=3.8$; Central and

3 (https://earthquake.usgs.gov)

South-East Europe (Shebalin et al., 1998) $45,85^{\circ} \mathrm{N} ; 15,95^{\circ} \mathrm{E} ; M=5.1 ; h=8.83 \mathrm{~km}$;

4 (http://terremoti.ingv.it/en/ event/24134961)

$b=1.5 ; v=4 ; c=3.8$; Central and

South-East Europe (Shebalin et al., 1998)

$263^{\circ} ; k=1.5$

$263^{\circ} ; k=1.5$

$263^{\circ} ; k=1.5$

$b=1.5 ; v=4 ; c=3.8$; Central and

$45.8773^{\circ} \mathrm{N}, 16.0208^{\circ} \mathrm{E} ; M_{L}=5.5$
$h=8.83 \mathrm{~km}$; Croatian survey

South-East Europe (Shebalin et al., 1998)

$45.79^{\circ} \mathrm{N} ; 16.07^{\circ} \mathrm{E} ; M_{s}=5.3 ; \mathrm{h}=12 \mathrm{~km}$;

6 Global CMT Catalog

$b=1.5 ; v=4 ; c=3.8$; Central and

South-East Europe (Shebalin et al., 1998)

$745.8773^{\circ} \mathrm{N}, 16.0208^{\circ} \mathrm{E} ; M_{L}=5.5$

$h=8.83 \mathrm{~km}$; Croatian Survey

$b=1.8 ; v=3.5 ; c=1.4$; Balkan region for $h$

$\leq 10 \mathrm{~km}$ (Shebalin, 1974, 1982)

$8 \quad 45.8773^{\circ} \mathrm{N}, 16.0208^{\circ} \mathrm{E} ; M_{L}=5.5$

$h=8.83 \mathrm{~km}$; Croatian survey

$b=1.8 ; v=3.5 ; c=1.4$; Balkan region for

$h \leq 10 \mathrm{~km}$ (Shebalin et al., 1974, 1982)

$45,85^{\circ} \mathrm{N} ; 15,95^{\circ} \mathrm{E} ; M=5.1 ; h=8.83$

9 km; (http://terremoti.ingv.it/en/ event/24134961)

$b=1.8 ; v=3.5 ; c=1.4$; Balkan region for

$h \leq 10 \mathrm{~km}$ (Shebalin, 1974; 1982)

$45,85^{\circ} \mathrm{N} ; 15,95^{\circ} \mathrm{E} ; M=5.1 ; h=8.83$

$10 \mathrm{~km}$; (http://terremoti.ingv.it/en/ event/24134961)

$b=1.8 ; v=3.5 ; c=1.4$; Balkan region for $h \leq 10 \mathrm{~km}$ (Shebalin et al., 1974; 1982)

$263^{\circ} ; k=1.5$

$263^{\circ} ; k=1.5$

$263^{\circ} ; k=1.5$

$57^{\circ} ; k=1.5$

$263^{\circ} ; k=1.5$

$57^{\mathrm{o}} ; k=1.5$

$b=1.52 ; v=3.62 ; c=3.16$; Calibrated coefficients for Caucasus (Frolova et al., 2019)

$45.8773^{\circ} \mathrm{N}, 16.0208^{\circ} \mathrm{E} ; M_{L}=5.5$ $h=8.83 \mathrm{~km}$; Croatian Survey $45,85^{\circ} \mathrm{N} ; 15,95^{\circ} \mathrm{E} ; M=5.1 ; h=8.83$

$12 \mathrm{~km}$; (http://terremoti.ingv.it/en/ event/24134961)

$45,85^{\circ} \mathrm{N} ; 15,95^{\circ} \mathrm{E} ; M=5.1 ; h=8.83$

$13 \mathrm{~km}$; (http://terremoti.ingv.it/en/ event/24134961)

$b=1.52 ; v=3.62 ; c=3.16$; Calibrated coefficients for Caucasus (Frolova et al., 2019)

$b=1.5 ; v=3.5 ; c=3.0$ default (Shebalin, 1977)

$1445.79^{\circ} \mathrm{N} ; 16.07^{\circ} \mathrm{E} ; M_{s}=5.3 ; h=12 \mathrm{~km}$; Global CMT Catalog

$b=1.5 ; v=4.5 ; c=4.5$ Balkan region,

$h>10 \mathrm{~km}$ (Shebalin et al., 1974)

$45.8773^{\circ} \mathrm{N}, 16.0208^{\circ} \mathrm{E} ; M_{s}=5.0$

$15 h=8.83 \mathrm{~km}$;

Croatian survey

$1645.8773^{\circ} \mathrm{N}, 16.0208^{\circ} \mathrm{E} ; M_{s}=5.0$ $h=8.83 \mathrm{~km}$; Croatian survey

$45,85^{\circ} \mathrm{N} ; 15,95^{\circ} \mathrm{E} ; M=5.0 ; h=8.83$

$17 \mathrm{~km}$; (http://terremoti.ingv.it/en/ event/24134961)

$b=1.5 ; v=4 ; c=3.8$; Central and

South-East Europe (Shebalin et al., 1998)

$263^{\circ} ; k=1.5$

$263^{\circ} ; k=1.5$

$263^{\circ} ; k=1.5$

$263^{\circ} ; k=1.5$

$263^{\circ} ; k=1.5$

$b=1.52 ; v=3.62 ; c=3.16$; Calibrated coefficients for Caucasus (Frolova et al., 2019)

$b=1.5 ; v=4 ; c=3.8$; Central and

South-East Europe (Shebalin et al., 1998)

$263^{\circ} ; k=1.5$

$45,85^{\circ} \mathrm{N} ; 15,95^{\circ} \mathrm{E} ; M=5.0 ; h=8.83$

$18 \mathrm{~km}$; (http://terremoti.ingv.it/en/ event/24134961)

$b=1.52 ; v=3.62 ; c=3.16$; Calibrated coefficients for Caucasus (Frolova et al., 2019)

$263^{\circ} ; k=1.5$

$1945.79^{\circ} \mathrm{N} ; 16.07^{\circ} \mathrm{E} ; M_{s}=5.3 ; h=12 \mathrm{~km} ; \quad b=1.52 ; v=3.62 ; c=3.16$; Calibrated coef-

19 Global CMT Catalog

ficients for Caucasus (Frolova et al., 2019)

$263^{\circ} ; k=1.5$ 
regional coefficients $(b, v, c)$ in the macroseismic field equation (1) were suggested for the Balkan region (Shebalin et al., 1974, 1977, 1982, 1998):

$$
I=b M-v \lg \sqrt{\Delta^{2}+h^{2}}+c
$$

where $\Delta$ is epicentral distance $(\mathrm{km}), h$ is hypocentral depth $(\mathrm{km})$, and $\mathrm{M}$ is the magnitude (Shebalin, 1968). We also used the macroseismic coefficients for a similar region in the Caucasus (Frolova et al., 2019, 2020) and different values of the flattening ratio $k=b / a$, the ratio of the large $b$ and small $a$ axis of the elliptical isoseismals of the highest intensity grades. The macroseismic field was oriented at $263^{\circ}$ and at $57^{\circ}$, according to the fault-plane solutions as determined by different surveys (https://earthquake.usgs.gov; http://mseism.gsras.ru; http:// www.globalcmt.org).

It should be noted that, when shaking intensities are obtained using the macroseismic field equation (1), surface wave magnitude $M s$ should be used. Calibration studies are usually based on data for large earthquakes $(M s \geq 6.0)$, since these are damaging events. Still there are cases when a shallow earthquake with $\mathrm{M}=5.0-5.5$ or even less can result in an impact characterized by intensity VI or occasionally higher. This is typical for the Zagreb epicentral zone in Croatia during the time span between the Great Zagreb earthquake of 1880 and the Zagreb event of 22 March 2020 (Herak et al., 1996, 2009; Markušić et al., 2020).

For large earthquakes with $6 \leq M w \leq 8$, based on the relationship derived by Kanamori (1983) and Lutikov et al. (2016), the discrepancy between $M s$ and $M_{w}$ is insignificant and can be neglected. The same cannot be said for earthquakes with moderate magnitudes $\left(3 \leq M_{w} \leq 5\right)$.

Similarly, as in Tab. 1, we show in Tab. 2 input data for computation with the "Extremum" system for the Petrinja 2020 earthquake. The macroseismic field was oriented at angles of $49^{\circ}, 132^{\circ}$ and $224^{\circ}$ according to the determined mechanism solution (https://earthquake.usgs.gov; https://ingvterremoti.com; http://www.globalcmt.org).

In this study we used the principle of analogy for one of the Alpine-Himalayan belt regions, viz., the Caucasus. In this region, seismic moments $M_{0}$ were determined from the spectra of moderate and low magnitude earthquakes, and the values of $M w$ were calculated (2). We used data from the GCMT catalogs for the period 1976-2014 (http://www.globalcmt.org/) for moment magnitudes, USGS NEIC (http://earthquake.usgs.gov/contactus/golden/neic.php) for surface wave magnitudes, and a catalog with energy classes $K p$ and spectral magnitudes $M_{w}$ for events within the range $3.8 \leq M_{s} \leq 5.1$ in the North Caucasus region. The following equation was obtained

$$
M_{w}=(0.876 \pm 0.102) M_{s}+0.774 \pm 0.441, R \approx 0.865\left(2.2 \leq M_{s} \leq 5.3\right),
$$

where $R$ is the correlation coefficient. 
Table 2. Variants of input data for the 29 December 2020 Petrinja earthquake for possible impact computation using the "Extremum" system.

No. Event parameters and source

1

$45,560^{\circ} \mathrm{N} ; 16,170^{\circ} \mathrm{E} ; M=6.7 ; h=10 \mathrm{~km} ;$ (http://mseism.gsras.ru)

$245,422^{\circ} \mathrm{N} ; 16,225^{\circ} \mathrm{E} ; M=6.4 ; h=10 \mathrm{~km}$;

2 (https://earthquake.usgs.gov)

3

4

5

6

7

8

9

$45,422^{\circ} \mathrm{N} ; 16,225^{\circ} \mathrm{E} ; M=6.4 ; h=10 \mathrm{~km} ;$ (https://earthquake.usgs.gov)

10

$45.4002^{\circ} \mathrm{N}, 16.2187^{\circ} \mathrm{E}, M=6.2 ; h=11.5$

km; (https://www.pmf.unizg.hr)

$1145.4002^{\circ} \mathrm{N}, 16.2187^{\circ} \mathrm{E}, M=6.2 ; h=11.5$ km; (https://www.pmf.unizg.hr)

12

$45.4002^{\circ} \mathrm{N}, 16.2187^{\circ} \mathrm{E}, M=6.2 ; h=11.5$ km; (https://www.pmf.unizg.hr)

13 $45.4002^{\circ} \mathrm{N}, 16.2187^{\circ} \mathrm{E}, M=6.2 ; h=11.5$ km; (https://www.pmf.unizg.hr)

14 $45.38^{\circ} \mathrm{N} ; 16.21^{\circ} \mathrm{E} ; M s=6.4 ; h=12 \mathrm{~km}$; (http://www.globalcmt.org)

15

$45.38^{\circ} \mathrm{N} ; 16.21^{\circ} \mathrm{E} ; M s=6.4 ; h=12 \mathrm{~km}$; (http://www.globalcmt.org)

$1645.38^{\circ} \mathrm{N} ; 16.21^{\circ} \mathrm{E} ; M s=6.4 ; h=12 \mathrm{~km}$; (http://www.globalcmt.org)
Coefficients of macroseismic filed equation (1) (Shebalin, 1968)

Field orientation and ratio coefficient $k$

$b=1.52 ; v=3.62 ; c=3.16$; Calibrated coefficients for Caucasus (Frolova et al., 2019)

Along faults; $k=2$

- “ -

$b=1.5 ; v=4 ; c=3.8$; Central and South-

East Europe (Shebalin et al., 1998)

$b=1.5 ; v=4.5 ; c=4.5$;

Balkan region, $h>10 \mathrm{~km}$ (Shebalin et al., 1974)

$b=1.5 ; v=3.5 ; c=4.5$;

Balkan region, $\mathrm{h} \leq 10 \mathrm{~km}$ (Shebalin et al., 1974)

$b=1.52 ; v=3.62 ; c=3.16 ;$ Calibrated coefficients for Caucasus (Frolova et al., 2019)

$$
\text { - " - }
$$

$b=1.52 ; v=3.62 ; c=3.16 ;$ Calibrated coefficients for Caucasus (Frolova et al., 2019)

$b=1.52 ; v=3.62 ; c=3.16$; Calibrated

coefficients for Caucasus (Frolova et al., $132^{\circ} * * * ; k=2$ 2019)

$b=1.52 ; v=3.62 ; c=3.16 ;$ Calibrated coefficients for Caucasus (Frolova et al., 2019)

$132^{\circ} * * * ;$
$k=1.5$
$-"-$
$-\cdots$
$-\cdots$
$-\cdots$
$-\cdots$

\footnotetext{
* https://ingvterremoti.com/2020/12/29/terremoto-mw-6-2-in-croazia-29-dicembre-2020-ore-1219/

** https://earthquake.usgs.gov

*** http://www.globalcmt.org
}

This relation shows that $M_{s}=4.8$ for $M_{w}=5.0$. The authors, being aware of the insufficiently representative sample for a reliable analysis, consider it as preliminary and will improve this relationship in the future when more data on the study area will be available. 


\section{Results and discussion}

\subsection{The 2020 Zagreb earthquake}

Figures 1 and 2 illustrate a comparison of simulated and observed (published) intensities according to USGS DYF ("Did You Feel" from the USGS web
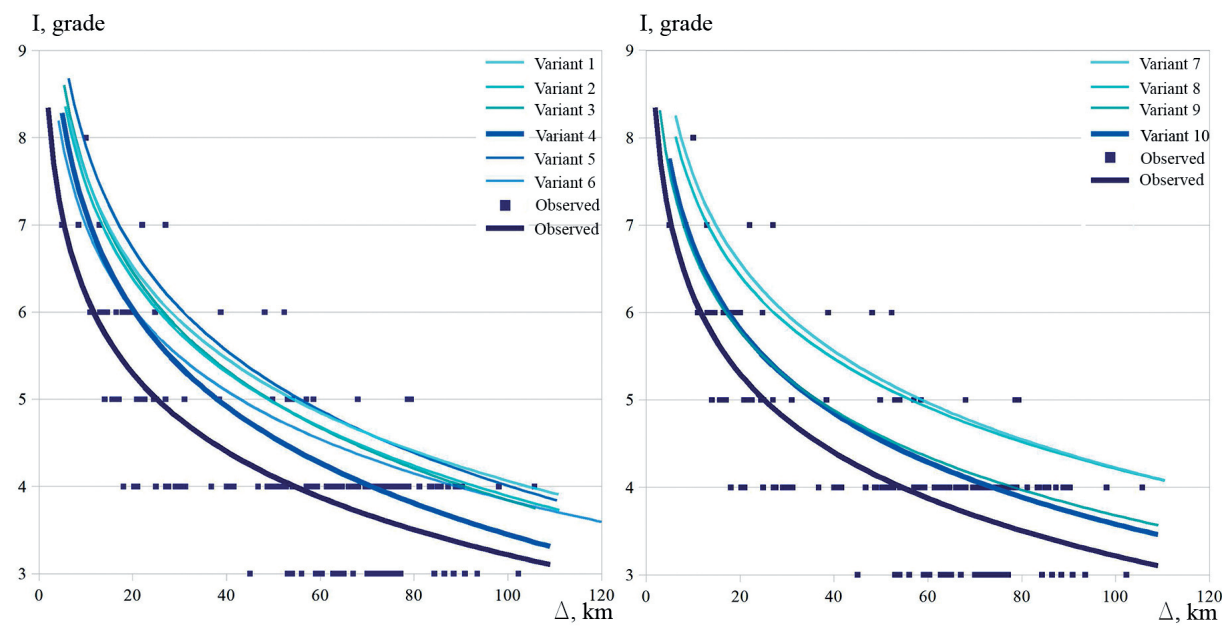

Figure. 1. Comparison of simulated intensities according to different variants (see Tab. 1) with published and observed intensities (https://earthquake.usgs.gov/earthquakes/eventpage/us70008dx7-/dyfi/ intensity).
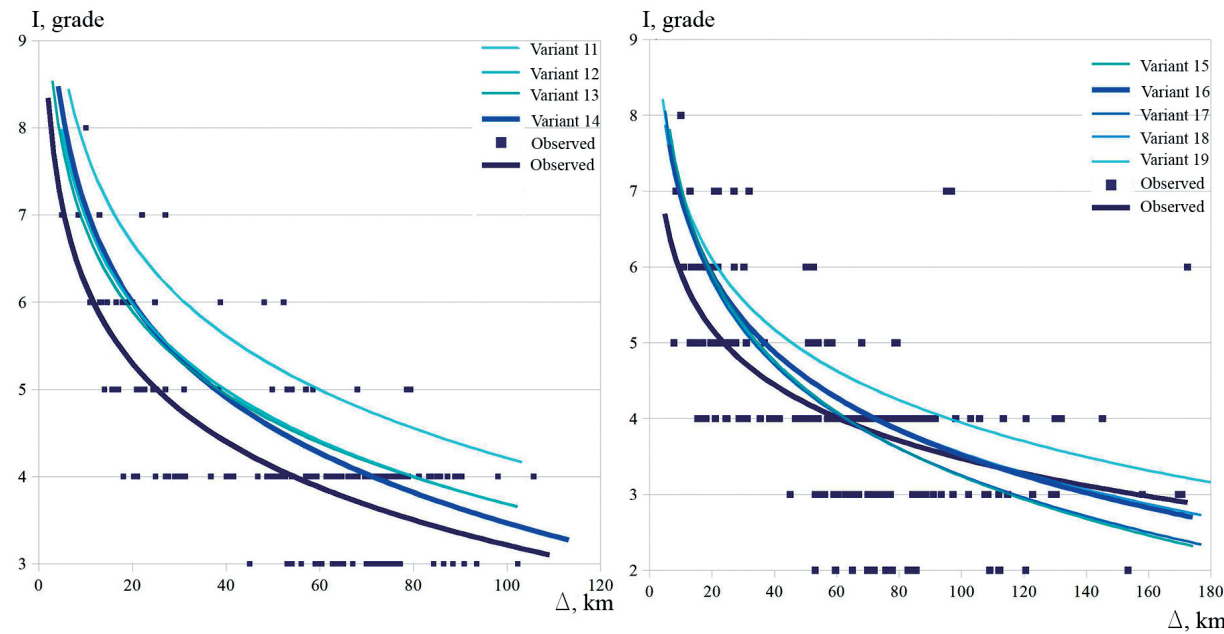

Figure 2. Comparison of simulated intensities according to different variants (see Tab. 1) with published/observed intensities (https://earthquake.usgs.gov/earthquakes/eventpage/us70008dx7-/dyfi/ intensity). 
site). With dark blue squares are displayed the observed values and with dark blue line best fitting curve. With other colors are shown curves that correspond to different variants of input data (see Tab. 1).

We discovered no significant influence related to the macroseismic field orientation and $k$, because the affected area is characterized by uniform population density.

For variants 1-6 (Fig. 1 left), the simulated intensities are overestimated compared with the observed/published intensities estimated by interactive questionnaires at the USGS website. At distances up to $40 \mathrm{~km}$, the excess is $0.1-0.3$ intensity grades, at larger distances it may reach a whole grade. The smallest discrepancy is observed for input data with the earthquake parameters determined by the Italian seismological service (variant 4 in Tab. 1). The use of the regional field coefficients for the Balkan region (events at depths $h \leq 10 \mathrm{~km}$ ) still overestimates the theoretical values, with the difference varying between 0.1 and 0.3 grades when using the source parameters based on the data of the Italian seismological service at all epicentral distances.

Figure 3 shows the results of comparison of simulated and observed intensity values collected in the field by the Croatian team.

When analyzing the simulated intensities along with "real" intensities, it is rather surprising to find significant differences between observed values published at the USGS web site and those collected in the field by the Croatian team (Fig. 4).

Figures 5 and 6 also demonstrate fairly good agreement between simulated and reported/observed effects, provided that suitable earthquake param-

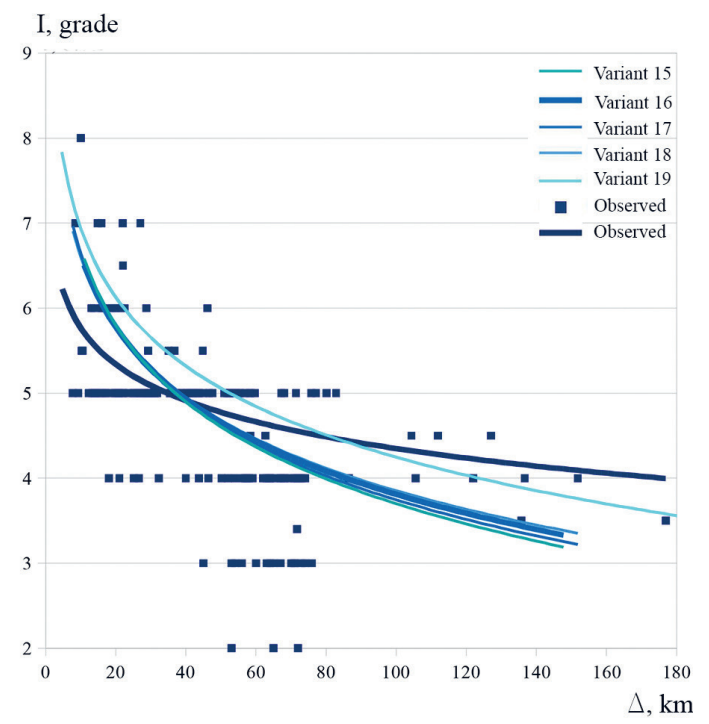

Figure 3. Comparison of simulated intensities according to different variants (see Tab. 1) with "real data" collected in the field by the Croatian team. 


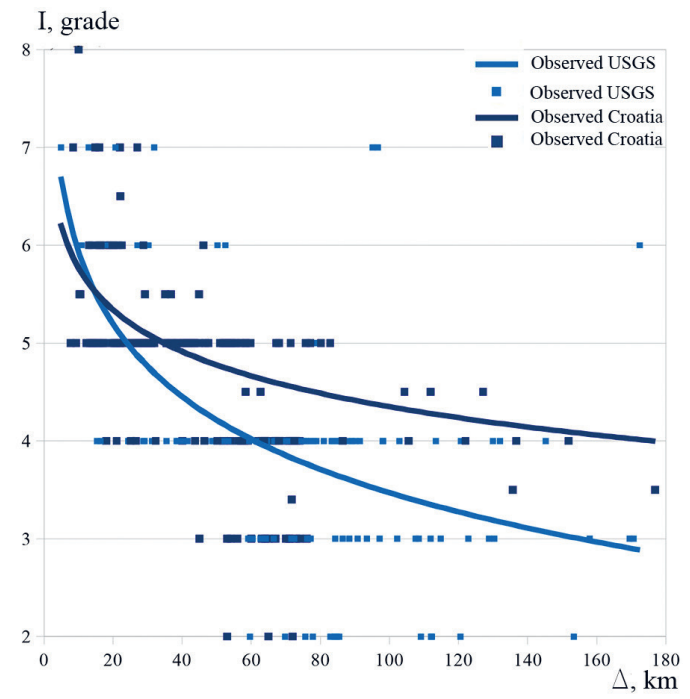

Figure 4. Comparison of observed intensities according to USGS DYF and "real data" collected in the field by the Croatian team.

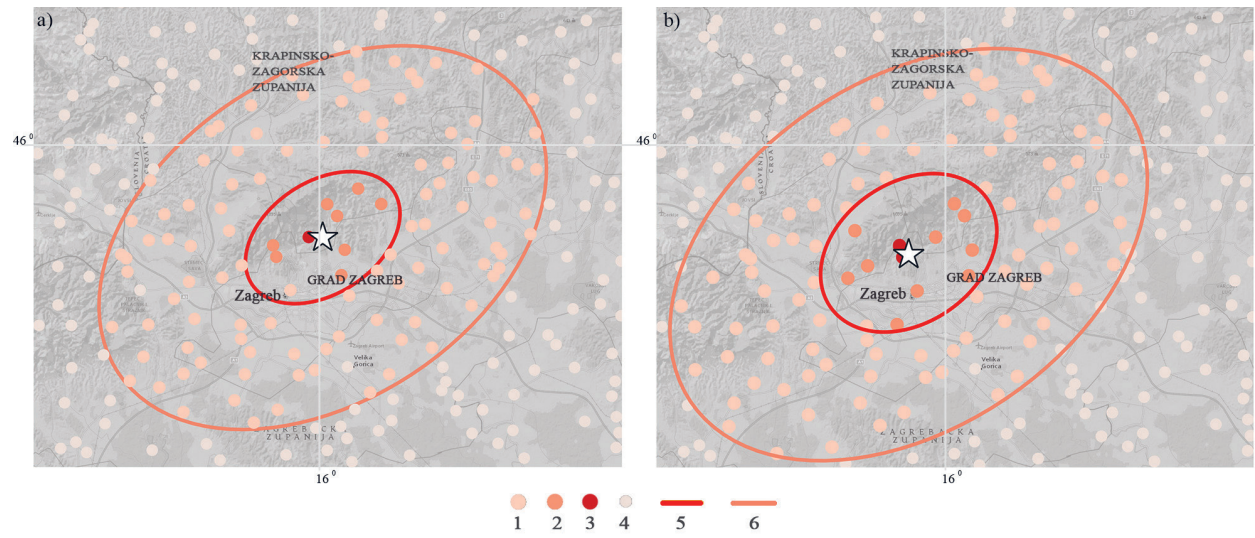

Figure 5. Simulated effects of the 22 March 2020 Zagreb earthquake with those produced by the "Extremum" system; average state of damage $d_{\text {ave }}$ : (1) $d=1 ;(2) d=2 ;(3) d=3$; (4) no damage; $(5,6)$ boundaries of zones with moderate damage $d=2$ and slight damage $d=1 ; a$ ) Variant 16 ; $b$ ) Variant 18 (see Tab. 1).

eters and regional coefficients of macroseismic field equation (1) have been chosen.

For epicentral distances of up to $40 \mathrm{~km}$, all variants overestimated somewhat the intensity values compared with the observed intensities, which is satisfactory for a first rapid assessment of the potential hazard immediately after the earthquake. Looking at the whole range of epicentral distance (up to $180 \mathrm{~km}$ ), the best agreement of the observed intensities is with variant 19. Inspecting the spatial distributions, we see that variant 16 also gives a satisfactory rapid result. 


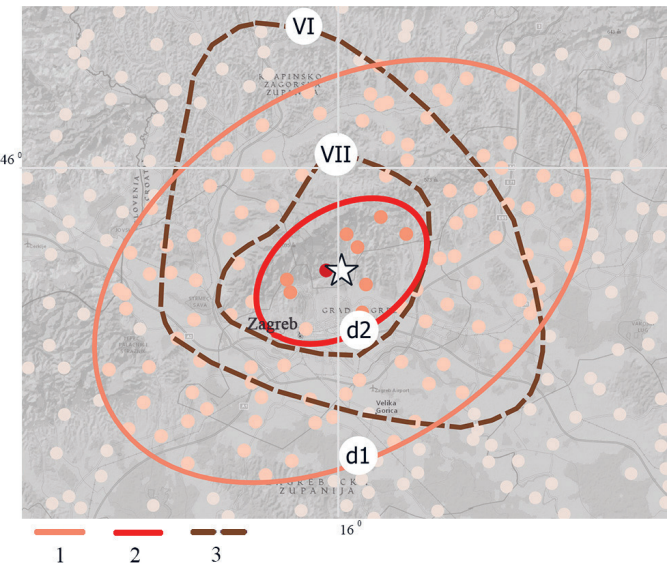

Figure 6. Comparison of simulated and observed/reported effects for variant 16 (see Tab. 1); 1 and 2 boundaries of zones with moderate damage $d=2$ and slight damage $d=1$; three dashed lines show the observed intensities according to the REPORT "CROATIA EARTHQUAKE Rapid Damage and Needs Assessment 2020" (C) June 2020, Government of Croatia The Croatia Earthquake - Rapid Damage and Needs Assessment 2020 report was prepared by the Government of Croatia, with the support of the World Bank. 102P. or according to the Seismological Survey of the Department of Geophysics at the Faculty of Science, University of Zagreb.

\subsection{The 2020 Petrinja earthquake}

Figures 7 and 8 display simulated and reported/observed intensities for the 29 December 2020 Petrinja earthquake.

Analysis of the above plots showed once more the importance of accurate earthquake parameters provided by the associated national survey when available. For the 29 December 2020 earthquake, the smallest residuals between simulated and reported intensities were obtained using the macroseismic field coefficients proposed by N.V. Shebalin for Central and South-Eastern Europe and for the Balkan region with $h>10 \mathrm{~km}$, as well as the calibrated field parameters

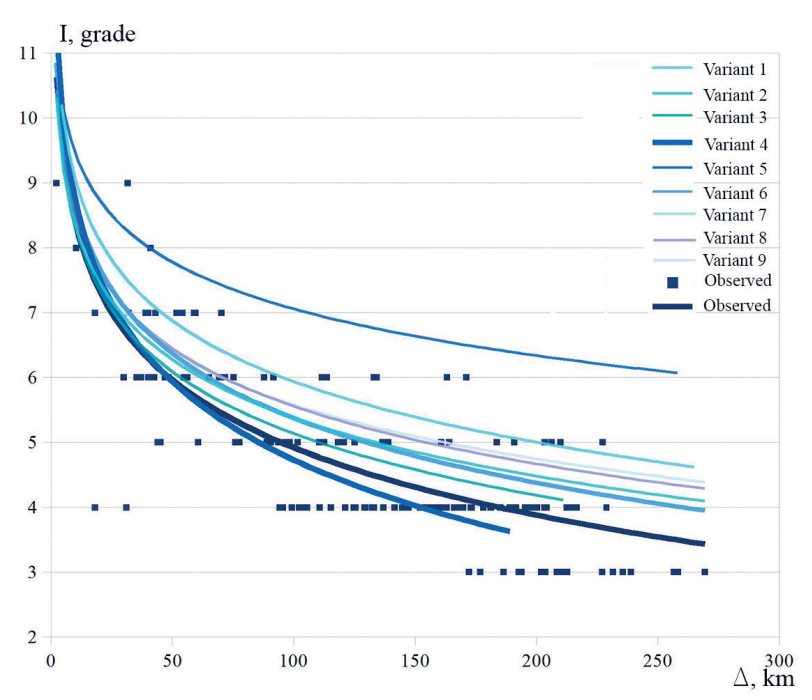

Figure 7. Comparison of simulated intensities according to different variants (see Tab. 2) with reported intensities of USGS DYF (https://earthquake.usgs. gov). 

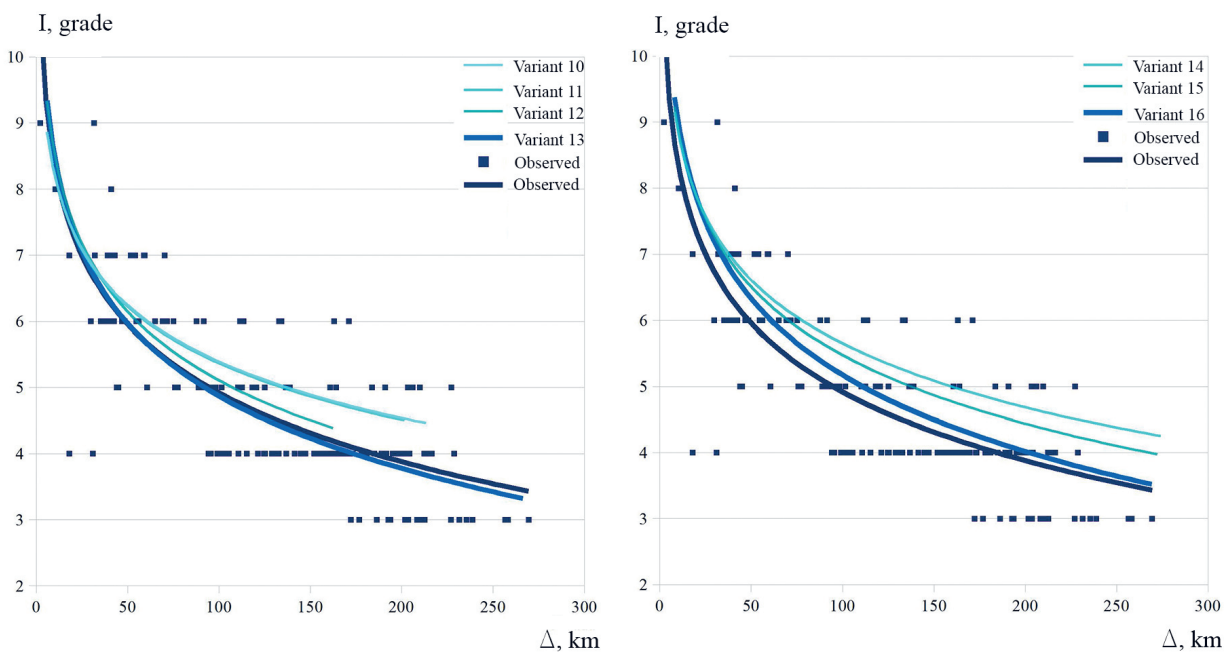

Figure 8. Comparison of simulated intensities according to different variants (see Tab. 2) with internet intensities of USGS DYF (https://earthquake.usgs.gov).

for the analogous zone in the Caucasus. Comparison of simulated and reported intensities for some population centers (Tab. 3) shows rather good agreement.

The calibration of the "Extremum" system models makes it possible to obtain quite reliable estimates of the possible intensity and damage in the emergency mode. The results can be presented in the form of tables indicating the names of city/town/village, their coordinates, the numbers of inhabitants, possible intensity value, the likelihood of different states of damage, and the average state of damage for the city/town/village as a whole. Figure 9 shows a visualization of the effects of the 29 December 2020 earthquake in accordance with variant 13 (Tab. 2). In this figure, the size of symbols indicates the number of inhabitants and the color of symbols represents the average state of damage for the structures.

Table 3. Simulated and reported intensities in the most affected cities and towns for the earthquake of 29 December 2020.

\begin{tabular}{lcccccccccc}
\hline \multirow{2}{*}{ City/town } & \multicolumn{9}{c}{ Simulated intensities, $I$, according to different variants (Tab. 2) } & \multicolumn{3}{c}{$\begin{array}{c}\text { Reported } \\
\text { intensities, } I\end{array}$} \\
\cline { 2 - 10 } & No. 3 & No. 4 & No. 6 & No. 10 & No. 11 & No. 12 & No.14 & No.15 & $I^{*}$ & $I^{* *}$ \\
\hline Petrinja & 9.35 & 9.55 & 9.25 & 8.41 & 8.48 & 8.57 & 8.57 & 8.63 & IX & VIII \\
Sisak & 8.88 & 9.02 & 8.92 & 7.67 & 7.83 & 7.84 & 7.96 & 7.00 & VIII & VII \\
Glina & 8.58 & 8.68 & 8.66 & 7.94 & 8.07 & 8.12 & 6.42 & 8.55 & VII & \\
Brest & 9.19 & 9.36 & 9.13 & 8.35 & 8.43 & 8.51 & 8.51 & 8.57 & & VIII \\
Zagreb & 6.09 & 5.88 & 6.26 & 6.62 & 6.57 & 6.45 & 6.80 & 6.67 & VI-VII & VI \\
\hline
\end{tabular}

*https://earthquake.usgs.gov/earthquakes/-eventpage/us6000d3zh/dyfi/responses

$* *$ https://www.gdacs.org 


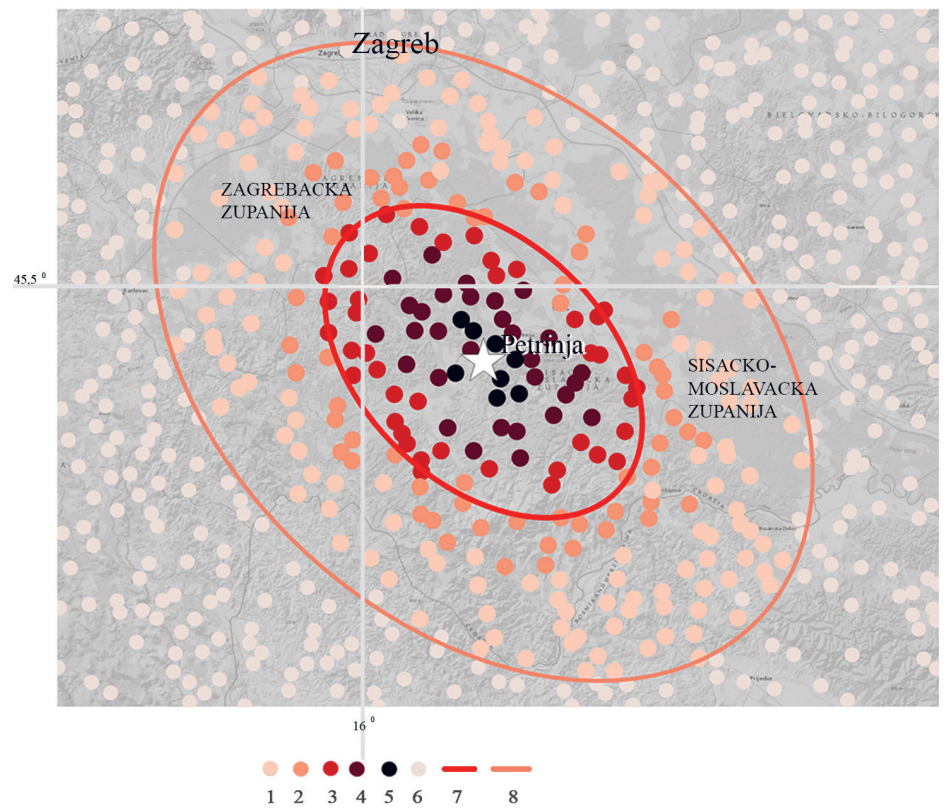

Figure. 9. Simulated consequences of the 29 December 2020 earthquake obtained using the "Extremum" system average state of damage: (1) slight $d=1$; (2) moderate $d=2$; (3) heavy $d=3$; (4) partial collapse $d=4$; (5) total collapse $d=5$; (6) no damage; $(7,8)$ boundaries of zones with heavy damage $(d=3)$ and slight damage $(d=1)$.

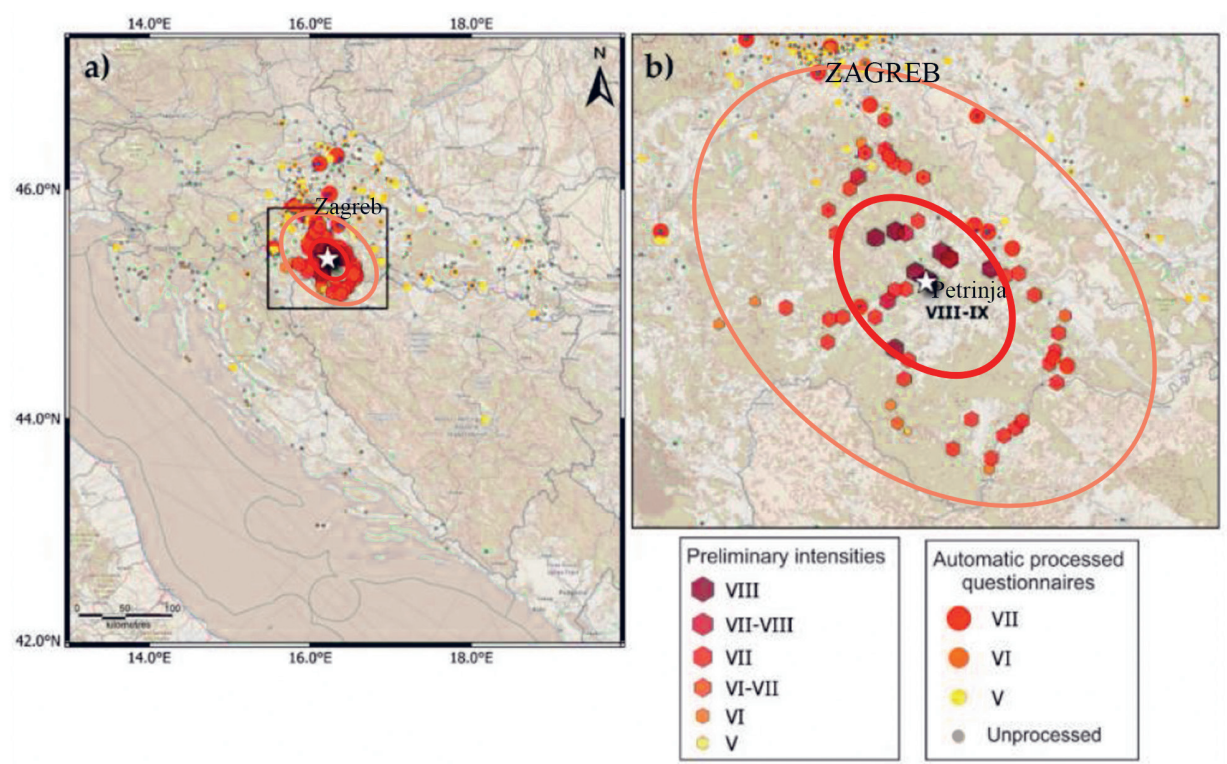

Figure 10. Map of observed intensities (from Markušić et al., 2021). 
In the case of the Petrinja 2020 earthquake, all variants gave satisfactory agreement. Comparison of Figs. 9 and 10 shows that the calculated intensities obtained within 20-30 min after the determination of the earthquake parameters almost coincide with the observed ones obtained from the responses of residents as reported at the website of the Croatian Seismological Survey and from field observations.

\section{Conclusions}

The results summarize calculations of the impact for two earthquakes which occurred in Croatia in 2020 and the importance of calibration for the "Extremum" system models in order to increase the reliability of loss estimates in near real time.

For the 2020 Zagreb earthquake, the results for epicentral distances up to $40 \mathrm{~km}$ in all variants overestimated the intensity values somewhat compared with the observations, with the best agreement being for variants 16 and 19 .

In the case of the Petrinja earthquake, all variants gave satisfactory agreement. The calculated intensities obtained within 20-30 min after the determination of the earthquake parameters almost coincide with the observations obtained from the responses of residents available at the website of the Croatian Seismological Survey and from the observations.

The next step towards a better calibration of the "Extremum" system itself is to determine the parameters of the modelled macroseismic ellipse according to the seismotectonic characteristics of the area concerned, and to obtain a solution consisting of several variants combined with different weight factors.

However, even in this study, the "Extremum" system proved to be satisfactory for a first rapid assessment of damage after an earthquake, when the most important activities (necessary emergency services in the protection of human lives) should be organized as soon as possible.

Acknowledgements - The research was carried out for the state projects No. AAAAA19-119021190077-6, No. 075-01304-20 and No. 175-11-2019-087 dated 18.12.2019 (Resolution № 218 of 09.04.2010, the Ministry of Science and Higher Education of the Russian Federation).

The authors thank their colleagues for continuing support and discussion of different steps for calibration of mathematical models derived by the "Extremum" System. Special thanks are extended to the staff of the Extreme Situations Research Center for their contribution to GIS environment development.

\section{References}

Frolova, N., Larionov, V. and Bonnin J. (2011): Earthquake casualties estimations in emergency mode, in: Advances in Natural and Technological Hazards Research, Springer, 29, 107-123.

Frolova, N. I., Larionov, V. I., Bonnin, J., Sushchev, S. P., Ugarov A. N. and Kozlov, M. A. (2017): Loss caused by earthquakes: Rapid estimates, Nat. Hazards, 88, 63-80,

https://doi.org/10.1007/s11069-016-2653-x. 
Frolova, N. I. and Ugarov, A. N. (2018): Knowledge base about past earthquakes consequences as a tool to increase the reliability of near real time loss estimation, Geoekologiya, 6, 1-18, https://doi.org/10.1134/S0869780318060017 (in Russian).

Frolova, N. I., Gabsatarova, I. P., Petrova, N. V., Ugarov, A. N. and Malaeva, N. S. (2019): Influence of shaking intensity attenuation peculiarities on reliability of earthquake loss estimation in emergency mode, Geoekologiya, 5, 23-37, https://doi.org/10.31857/S0869-78092019523-37 (in Russian).

Herak, M., Herak, D. and Markušić, S. (1996): Revision of the earthquake catalogue and seismicity of Croatia, 1908-1992, Terra Nova, 8, 86-94, https://doi.org/10.1111/j.1365-3121.1996.tb00728.x.

Herak, D., Herak, M. and Tomljenović, B. (2009): Seismicity and earthquake focal mechanisms in North-Western Croatia, Tectonophysics, 465, 212-220, https://doi.org/10.1016/j.tecto.2008.12.005.

Kanamori, H. (1983): Magnitude scale and quantification of earthquakes, Tectonophysics, 93, 185-199, https://doi.org/10.1016/0040-1951(83)90273-1.

Larionov, V. and Frolova, N. (2003): Peculiarities of seismic vulnerability estimations, in: Natural Hazards in Russia, 6: Natural Risks Assessment and Management, Publishing House "Kruk", Moscow, 120-131 (in Russian).

Larionov, V., Sushchev, S., Ugarov, A. and Frolova, N. (2003): Seismic risk assessment with GIStechnology application, in: Natural Hazards in Russia, 6: Natural Risks Assessment and Management, Publishing House "Kruk", Moscow, 209-231 (in Russian).

Lutikov, A. I. and Gabsatarova, I. P. (2016): Relationship between moment magnitude $\mathrm{M}_{\mathrm{w}}$ and surface wave magnitude Ms for the Caucasus region and adjacent territories, Geophys. Res., 17, 29-36.

Markušić, S., Herak, D., Ivančić, I., Sović, I., Herak, M. and Prelogović E. (1998): Seismicity of Croatia in the period 1993-1996 and the Ston-Slano earthquake of 1996, Geofizika. 15, 83-101.

Markušić, S. and Herak, M. (1999): Seismic zoning of Croatia, Nat. Hazards, 18, 269-285, https://doi.org/10.1023/A:1026484815539.

Markušić, S., Stanko, D., Korbar, T., Belić, N., Penava, D. and Kordić, B. (2020): The Zagreb (Croatia) M5.5 earthquake on 22 March 2020, Geosciences, 10, 252, https://doi.org/10.3390/geosciences10070252.

Markušić, S., Stanko, D., Penava, D., Ivančić, I., Bjelotomić Oršulić, O., Korbar, T. and Sarhosis, V. (2021): Destructive M6.2 Petrinja earthquake (Croatia) in 2020 - Preliminary multidisciplinary research, Remote Sens., 13, 1095, https://doi.org/10.3390/rs13061095.

Methods for forecasting the impact of earthquakes (2000): Moscow, VNII GOChS, Extreme Situations Research Center, Seismological Center of IGE RAS, 2000, 27 pp (in Russian).

Shebalin N. V. (1968): Procedures of engineering seismological data application for seismic zoning, Seismic zoning of the USSR, Moscow, Nauka, 95-121 (in Russian).

Shebalin, N. V., Karnik, V., Hadžievski, D. (eds) (1974): Catalogue of earthquakes. Part I, 1901-1970, Part II, prior to 1901, Part III, Atlas of isoseismal maps. UNDP/UNESCO Survey of the seismicity of the Balkan region, Skopje, 65 pp.

Shebalin, N. V. (1977): Reference earthquakes and macroseismic field equations, in: New catalogue of strong earthquakes for the USSR territory from ancient times till 1975. Nauka, Moscow, Russian Federation, 20-30 (in Russian).

Shebalin, N. V. (1982): in: Earthquake Risk Reduction in the Balkan Region. UNDP Project Executed by UNESCO in Association with UNDRO (RER/79/014). Working Group A. Seismology, Seismotectonics, Seismic Hazard and Earthquake Prediction. Final Report. Athens, December 1982, $157 \mathrm{pp}$.

Shebalin, N. V., Leydecker, G., Mokrushina, N. G., Tatevossian, R. E., Erteleva, O. O. and Vassiliev, V. Y. (1998): Earthquake Catalogue for Central and Southeastern Europe 342 BC - 1990 AD. Final Report to Contract ETNU-CT93-0087.

Shebalin, N., Gekhman, A. and Shestoperov, G. (1986) Development of improved version of seismic intensity scale (MMSK-86) on the bases of MSK-64 scale and scale of Joint Council on Seismology and Earthquake Engineering - 73. Report on scientific research study within the Federal Program 0.74.03, number of state registration 01814003271, Joint Council on Seismology and Earthquake Engineering, Academy of Sciences of the USSR, Moscow (in Russian). 
SAŽETAK

\title{
Kalibracija modela intenziteta potresne trešnje dobivenih primjenom sustava "Extremum" s ciljem simulacije potencijalnih gubitaka na primjeru potresa iz 2020. godine u Hrvatskoj
}

\author{
Snježana Markušić, Nina Frolova, Irina Gabsatarova, Sergej Suchshev \\ i Nataliya Malaeva
}

Ovaj rad je posvećen primjeni sustava "Extremum" za simulaciju gubitaka za dva potresa koji su se 2020. godine dogodili u Hrvatskoj. Predložen je postupak kalibracije matematičkih modela koji se koriste za simulaciju intenziteta podrhtavanja. Parametri regionalnog makroseizmičkog polja, kao što su koeficijenti jednadžbe makroseizmičkog polja, omjer između duže $(b)$ i kraće $(a)$ osi najviše eliptične izoseiste (koeficijent spljoštenosti je $k$ ), kut koji definira orijentaciju makroseizmičkog polja (azimut duže osi izoseizmalne elipse), temelje se na opsežnim makroseizmičkim podacima prikupljenima za područje Balkana i na podacima za analogno područje sa sličnim seizmotektonskim parametrima na Kavkazu. Dobivena je prilično dobra konzistentnost između rezultata simulacije na primjeru potresa u Hrvatskoj iz 2020. godine i opažanja, potvrđujući da je kalibracija makroseizmičkog modela pomoću sustava "Extremum" bila razumna i učinkovita s ciljem povećanja pouzdanosti za procjenu gubitaka u stvarnom vremenu.

Ključne riječi: modeliranje makroseizmičkog polja, gubitci uslijed potresa, procjene gotovo u realnom vremenu, potresi, Hrvatska, sustav za simulaciju gubitaka "Extremum"

\footnotetext{
Corresponding author's address: Snježana Markušić, Department of Geophysics, Faculty of Science, University of Zagreb, Horvatovac 95, HR-10000 Zagreb, Croatia; tel: +385 14605 913; e-mail: markusic@gfz.hr
} 